\title{
Follicle growth, corpus luteum function and their effects on embryo development in postpartum dairy cows
}

\author{
D. C. Wathes ${ }^{1}$, V. J. Taylor ${ }^{1}$, Z. Cheng ${ }^{1}$ and G. E. Mann ${ }^{2}$
}

${ }^{i}$ Reproduction and Development Group, Royal Veterinary College, Hawkshead Lane, North Mymms, Hatfield, Herts AL9 TTA, UK; and ${ }^{2}$ School of Biological Sciences, Division of Animal Physiology, University of Nottingham, Sutton Bonington, Loughborough,

Leicestershire LE12 5RD, UK

\begin{abstract}
Absent or irregular ovarian cycles in lactating dairy cows are caused by failure to ovulate the dominant follicle at the appropriate time. The follicle then either regresses or develops into a cyst. This process can be triggered by a variety of metabolic and disease factors that act at the hypothalamus and pituitary gland to inhibit pulsatile LH secretion and the LH surge, and at the ovary to reduce follicular growth and oestradiol production. Cows of poor energy status have low circulating concentrations of insulin-like growth factor I (IGF-I). Predisposing factors include calving difficulties, inappropriate diet, reduced intake of dry matter and a high rate of body condition score loss. Various stressors predispose the follicle to cyst development by inhibiting the $\mathrm{LH}$ surge and ovulation; these include common infections, such as mastitis. Even when ovulation does occur, poor follicular development may result in production of an inadequate corpus luteum. The timing of the increase in progesterone in the early luteal phase (days 4-5) appears to be a key determinant of fertility, probably because it alters the secretory activity of the reproductive tract, thus influencing embryonic growth and interferon- $\tau$ production. A period of negative energy balance after calving can reduce fertility even though metabolic parameters have apparently improved at the time of service.
\end{abstract}

\section{Introduction}

Failure to ovulate occurs under two scenarios in the postpartum dairy cow. After calving, a succession of follicles may grow and regress before one follicle reaches sufficient size and produces sufficient oestradiol to trigger an LH surge and ovulation (Roche and Diskin, 2001). The second situation occurs later in the postpartum period when some cows fail to re-ovulate after an initial resumption of cyclicity (Bulman and Wood, 1980; Huszenicza et al., 1988). This situation may lead to an extended inter-luteal interval and in extreme cases the cow reverts to a prolonged anoestrous period. These two conditions have been termed delayed ovulation 
type 1 and 2 (DOV1 and DOV2), respectively. Several recent studies have investigated the sequential chain of events that occur within an individual follicle as it achieves dominance or undergoes atresia (for a review, see Bao and Garverick, 1998). The consensus is that the key regulators after calving are an increasing LH pulse frequency acting in synergy with an adequate concentration of the growth factors insulin and insulin-like growth factor I (IGF-I) (Butler, 2001 ; Roche and Diskin, 2001).

Until recently, little was known about the relationship between pre-ovulatory follicle development and subsequent luteal function after ovulation in naturally cyclic animals, although previous studies in cattle have shown that follicles destined to form short-cycle corpora lutea show reduced oestradiol secretion and have fewer LH receptors (Inskeep et al., 1988). However, early work using embryo transfer and steroid-treated ovariectomized ewes demonstrated that the successful development of an embryo is dependent on adequate luteal function promoting synchronous development of the reproductive tract (for a review, see Wathes, 1992).

In this paper, the factors that influence the interval to first ovulation and the adequacy of luteal function in the dairy cow are reviewed, and particular emphasis is placed on potential metabolic signals that may influence ovarian activity.

\section{Endocrine control of follicular growth}

\section{Gonadotrophins}

A transient increase in FSH at days 2-3 after parturition is followed by the emergence of a cohort of about three to six follicles of $4-6 \mathrm{~mm}$ in diameter; by day 10 , one of these follicles will have achieved dominance (Roche and Diskin, 2001). LH pulse frequency increases during the first 2 weeks after parturition and is higher in cows that ovulate their first dominant follicle in comparison with cows that do not (Beam and Butler, 1999). The LH pulse rate is reduced in cows that have not yet reached their nadir in negative energy balance, and in cows with hypoglycaemia or higher milk production (for a review, see Butler, 2001). The ruminant pituitary gland contains high concentrations of the type 1 IGF receptor (IGF-1R) and can respond to exogenous IGF-I by increasing LH release (Adam et al., 2000). The IGF-binding proteins (IGFBP-2, -3 and -5 ) are also present in the pituitary gland, and their concentration varies according to nutritional status (for data on ewes, see Snyder et al., 1999). These data indicate a direct inhibitory effect of adverse metabolic signals on the LH pulse generator, and that circulating IGF-I, modulated by IGFBPS, may alter the sensitivity of the pituitary gland to both luteinising hormone releasing hormone $(\mathrm{LHRH})$ and to oestradiol feedback.

\section{Insulin and IGFs}

The bovine ovary contains specific insulin and IGF receptors but, at supraphysiological concentrations, insulin can also act through the IGF-1R (Spicer and Echternkamp, 1995). Summarising data from a number of studies the following points emerge (Fig. 1).

(1) Although low expression of IGF-I mRNA may be present in some follicles, several lines of evidence show that the IGF-I measured in bovine follicular fluid is mainly, if not totally, derived from the circulation. The concentration of IGF-I in follicular fluid increases with increasing follicular diameter and is highly correlated with the plasma IGF-I concentration (Spicer and Echternkamp, 1995; Funston et al., 1996; Perks et al., 1999).

(2) IGF-II mRNA is localized to the theca. Its concentration is higher in small $(<5 \mathrm{~mm}$ diameter) follicles and its expression is greater in healthy follicles than in atretic small follicles (Perks etal, 1999). 


$\begin{array}{ccc}-50 \text { days } & -10 \text { days } & -1 \text { day } \\ <2.5 \mathrm{~mm} & 5 \mathrm{~mm} & 13-20 \mathrm{~mm}\end{array}$

\begin{tabular}{|c|c|c|c|}
\hline $\begin{array}{l}\text { IGF-II in } \\
\text { theca }\end{array}$ & Recruitment & $\begin{array}{l}\text { Selection and } \\
\text { growth }\end{array}$ & Ovulation \\
\hline $\begin{array}{l}\text { Gonadotrophin } \\
\text { requirements }\end{array}$ & $\begin{array}{l}\text { Postpartum FSH } \\
\text { surge }\end{array}$ & $\begin{array}{l}\text { Low FSH } \\
\text { Increasing LH } \\
\text { pulsatility }\end{array}$ & $\begin{array}{l}\text { LH surge } \\
\text { LH receptors on } \\
\text { granulosa }\end{array}$ \\
\hline Actions of IGFs & $\begin{array}{l}\text { Increase in } \\
\text { number of small } \\
\text { follicles }\end{array}$ & Increase proliferation & $\begin{array}{c}\text { Increase LH receptors } \\
\text { Enhance oestradiol } \\
\text { and progesterone } \\
\text { production }\end{array}$ \\
\hline Actions of insulin & & \multicolumn{2}{|c|}{ Stimulate oestradiol production } \\
\hline IGFBP-2,-4,-5 & \multicolumn{3}{|c|}{ Inhibit FSH-stimulated steroidogenesis and mitogenesis } \\
\hline IGFBP-3 & \multicolumn{3}{|c|}{$\begin{array}{l}\text { Inhibit LH-stimulated thecal proliferation and androstenedione } \\
\text { production }\end{array}$} \\
\hline
\end{tabular}

Fig. 1. Actions of insulin-like growth factors I and II (IGF-I and IGF-II) and insulin during different phases of follicular development in cows. NEB: negative energy balance. CL: corpus luteum. IGFBP: insulin-like growth factor binding proteins. Data from Spicer and Echternkamp (1995); Armstrong et al. (1996); Funston et al. (1996); Bao and Garverick (1998); Perks et al. (1999): Austin et al. (2001).

(3) IGF-1R are present on both theca and granulosa. Their concentration is also higher in healthy follicles than in small atretic $(<5 \mathrm{~mm})$ follicles and can be increased by epidermal growth factor, oestradiol and FSH (Spicer and Echternkamp, 1995; Perks et al., 1999).

(4) The lower MW IGFBPs $(-2,-4$ and -5$)$ are synthesized in the follicle wall and their concentration in follicular fluid decreases as the follicles grow and increases as they become atretic, thus regulating the bioavailability of free IGF within the follicle. Exogenous addition of IGFBPs in vitro can inhibit FSH stimulated steroidogenesis and mitogenesis in granulosa cells (Spicer and Echternkamp, 1995; Armstrong et al., 1996; Bao and Garverick, 1998; Austin et al, 2001).

(5) IGFBP-3 is also present in follicular fluid, but the main source is probably the circulation. IGFBP-3 can inhibit IGF-I-stimulated thecal proliferation and androstenedione production (Spicer and Echternkamp, 1995; Armstrong et al., 1996).

Although IGF-II is the main locally produced growth factor within the bovine ovary, there is little information available on its role. However, the different IGFBPs present in the follicle have different affinities for IGF-I and -11 , which may be physiologically important. IGFBP-2 and -5 both bind IGF-II with a greater affinity than IGF-I, whereas the affinities of IGFBP3 and -4 for the two peptides are similar (Rajaram et al., 1997). IGFBP-2 and -3 are also nutritionally sensitive, and concentrations of circulating IGFBP-2 increase and IGFBP-3 decrease in response to dietary restriction (Rajaram et al., 1997). After parturition in beef cows 
circulating IGFBP-2 at week 2 was higher and IGFBP-3 was lower in cows that remained anoestrus in comparison with cows that resumed cyclicity earlier (Roberts et al., 1997). Thus, it appears that the ability of follicles to grow and achieve dominance is regulated by both intrafollicular and endocrine IGF systems, which can be modified in response to nutritional status.

Although IGF-I and insulin have some functional overlap, there is considerable evidence that they have separate actions. Spicer and Echternkamp (1995) compared their effects on the ovary and they concluded that IGF-I was more mitogenic and that this effect was enhanced by gonadotrophin support in small $(<5 \mathrm{~mm})$, but not in larger follicles. Treatment of cows with bovine somatotrophin, which increases circulating IGF-I, stimulated the growth of small $(<5 \mathrm{~mm})$ follicles and the synergistic action of IGF-I with FSH on granulosa cell proliferation was found only on cells from small follicles (Gong et al., 1993). Both insulin and IGF-I enhanced LH stimulated androgen production by the theca. Insulin at physiological concentrations of $\leqslant 10 \mathrm{ng} \mathrm{ml}^{-1}$ had the more potent effect on oestradiol production in vitro, although there was some stimulation of oestradiol production by IGF-I in large ( $>8 \mathrm{~mm}$ ), but not in small follicles. Although the concentration of oestradiol and IGF-I in follicular fluid both increase as follicles grow, there is little correlation in their concentrations in individual follicles (Spicer and Echternkamp, 1995). Collectively, these data indicate that the growth and oestradiol production of bovine follicles are regulated separately: locally produced IGF-II and systemic IGF-I are mainly responsible for proliferation, particularly of small follicles, whereas insulin is the primary regulator of oestradiol production. Therefore, both factors are required for ovulation (Fig. 1).

It is pertinent to examine the profiles of insulin and IGF-I during this period to understand why some dominant follicles do not ovulate in the postpartum cow. Concentrations of insulin and IGF-I in cows were compared between first lactation and older cows (Fig. 2a,b) and between average and high yielding cows (Fig. 2c). In agreement with other studies (for example, see Butler, 2001), a negative relationship was found between the IGF-I concentration after calving and the interval to the resumption of ovarian cyclicity (Fig. $2 \mathrm{~d}$ ). The trend was similar in multiparous and primiparous cows although IGF-I concentrations were consistently much higher in the younger animals (Fig. 2b). Older cows with either DOV1 or DOV2 had similar insulin values to those in normally cyclic cows but acyclic primiparous cows showed a trend towards lower insulin concentrations $(P=0.09, \mathrm{~V}$. J. Taylor and $D$. C. Wathes, unpublished). In some situations, cows may have adequate insulin to promote oestradiol production, but insufficient IGF-I for proliferation; this could lead to the ovulation of a small follicle, resulting in the production of an undersize corpus luteum.

\section{Leptin}

Leptin is a $16 \mathrm{kDa}$ protein produced primarily by adipose cells, although leptin mRNA has been detected in other tissues including the liver and placenta. The circulating leptin concentration shows a positive correlation with the size of the fat depot and also varies with nutritional status, as leptin mRNA expression decreases during fasting (Tsuchiya et al., 1998). Leptin receptors have been identified in both the arcuate nucleus and median eminence of sheep (Keisler et al., 1999) and in bovine ovarian granulosa cells (Spicer, 2001a). In the hypothalamus leptin decreases appetite, thus feed intake is stimulated when leptin concentrations are low. In cattle, leptin concentrations show a marked decrease at about the time of parturition (Kadokawa ef al., 2000; Block et al., 2001). In lactating cows, the period of negative energy balance after calving has been linked to reduced leptin concentrations (Kadokawa et al., 2000; Block et al., 2001) and decreased leptin has been linked 

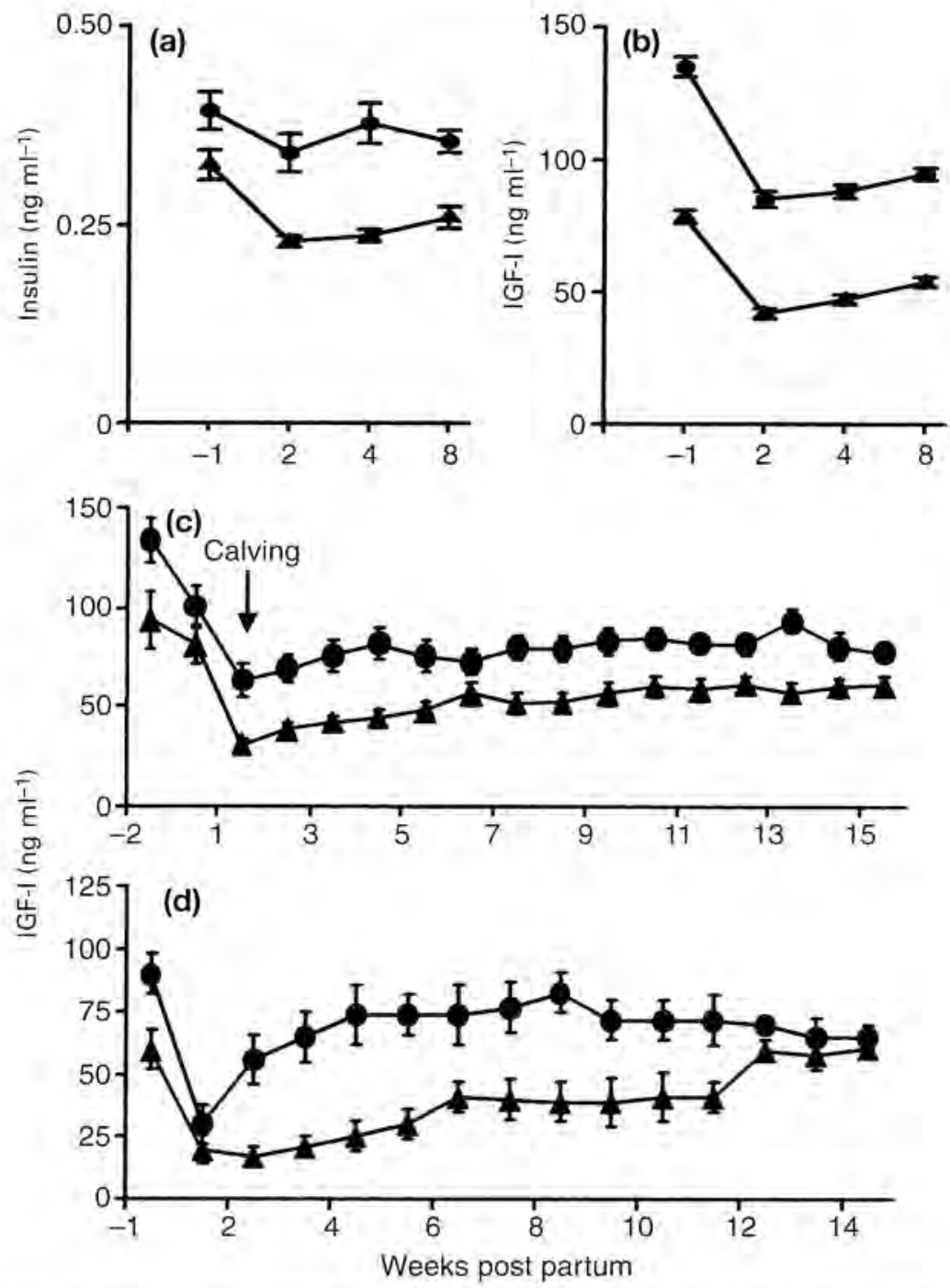

Fig. 2. Plasma concentrations of (a) insulin and (b-d) insulin-like growth factor I (IGF-I) before and after calving in lactating dairy cows. (a,b) Insulin and IGF-I measured in multiparous $(\mathbf{\Lambda}, n=160)$ and primiparous $(\bullet, n=$ 158) cows. (c) IGF-I in average genetic merit (, $8047 \pm 300 \mathrm{~kg}$ per 305 day lacation, $n=20)$ and high genetic merit $(\mathbf{\Lambda}, 10573 \pm 245 \mathrm{~kg}$ per 305 day lacation, $n=28$ ) cows. (d) IGF-l in multiparous cows with normal ovarian activity post partum $(\bullet, n=27)$ or in cows with a delayed ovulation type 1 profile $(\boldsymbol{\Lambda}, n=6)$. All values are mean \pm SEM. Note that both insulin and IGF-I concentrations were significantly higher in the first lactation than in older cows. IGF-I concentrations were significantly lower in high yielding cows and in cows with a delayed start to ovarian activity.

to delayed resumption of cyclicity (Kadokawa et al., 2000). Furthermore, once reproductive cyclicity has been re-established, the occurrence of cycle problems is associated with reduced plasma leptin concentrations (G. E. Mann and D. Blache, unpublished). Therefore, leptin represents another potential metabolic signal linking body condition to reproductive potential. 


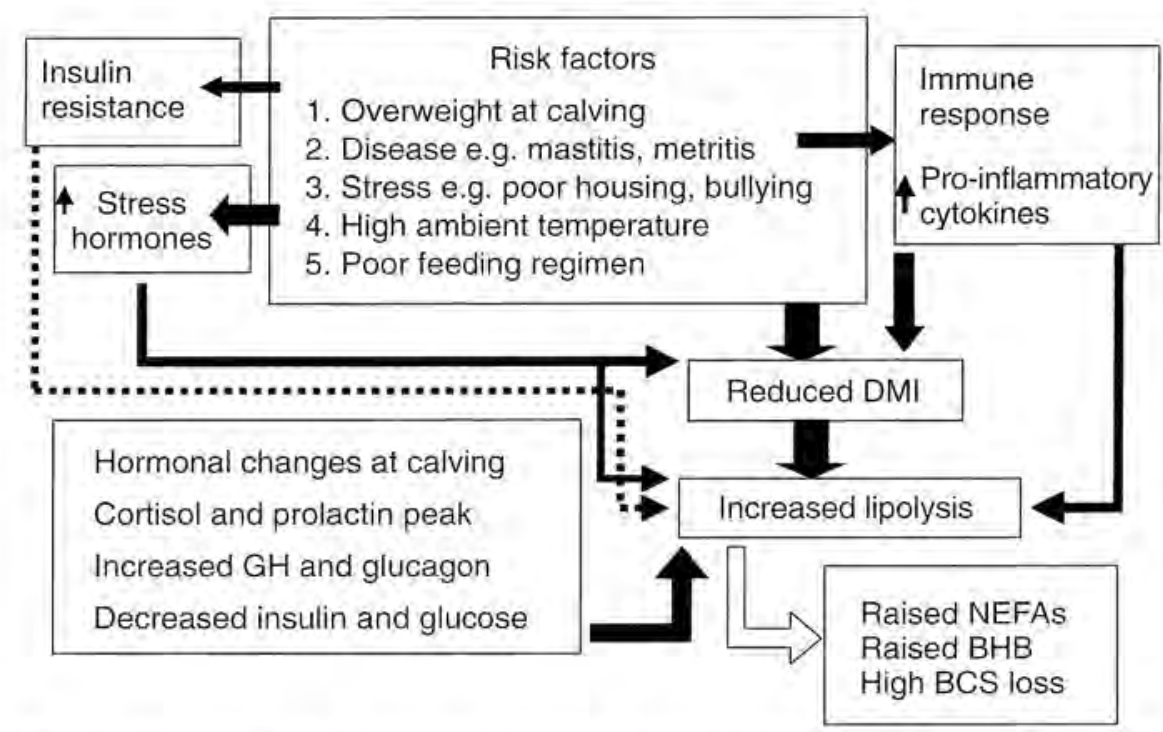

Fig. 3. Hormonal and metabolic changes in periparturient cows associated with high tissue mobilization and loss of body condition which predispose cows to poor fertility. BCS: body condition score; DMI: dry matter intake; GH: growth hormone; NEFA: non-esterified fatty acids; BHB: $\beta$-hydroxybutyrate.

\section{Metabolic signals and ovarian cyclicity}

\section{Background}

Dairy cows enter a period of negative energy balance in early lactation, which may last up to 20 weeks in high yielding cows. The shortfall in energy intake is met by extensive mobilization of body tissue. Cows in negative energy balance release non-esterifed fatty acids (NEFAs) from fat as an energy source and ketone bodies (acetone, acetoacetate and $\beta$-hydroxybutyrate) are produced by the liver as the fatty acids are metabolized. Therefore, circulating concentrations of both NEFA and $\beta$-hydroxybutyrate increase after calving to an extent that is related to the degree of fat mobilization (Fig. 3).

The constituents of the lactational diet also influence a number of circulating metabolites which may signal to the reproductive system. These relationships are complex (NRC, 1989) and can be summarized only briefly here. If the balance of concentrate to forage is excessive, cows may develop acidosis, leading to a reduction in dry matter intake (DMI) and a consequent worsening of the negative energy balance. Dairy cow diets typically contain a high crude protein concentration. The rumen degradable component is broken down during rumen fermentation, releasing ammonia which is used for microbial protein synthesis, a process requiring energy. If excess effective rumen degradable protein is fed in relation to the available fermentable metabolizable energy in the diet, then ammonia production will increase. Ammonia must be detoxified to urea by the liver, so urea concentrations increase. The detoxification procedure requires energy, thus exacerbating the negative energy balance (Laven and Drew, 1999).

Fats are included in the lactational diet as an energy source and both the type and amount may be important. Excess fat can depress appetite and, thus, reduce the DMI. The proportion of unsaturated and polyunsaturated fats (PUFAs) that the diet contains also varies. The n-6 PUFAs 
are derived from linoleic acid (LA, 18:2, n-6) and predominate in plant oils (for example, soyabean). The n-3 PUFAs are derived from linoleic acid (LNA, 18:3, n-3), which is present in green leaf forages and linseed, and include the longer chain PUFAs eicosapentaenoic acid $(20: 5, n-3)$ and docosahexaenoic acid $(22: 6, n-3)$, which are constituents of fish oil. As well as providing energy, PUFAs act as precursor molecules for prostaglandin synthesis and the ratio of different types of PUFA in cell membranes can alter the amount and type of prostaglandins produced (for reviews, see Abayasekara and Wathes, 1999; Mattos et al., 2000). Arachidonic acid (AA, 20:2, n-6) has also been implicated in steroidogenesis by increasing the expression of steroidogenic acute regulatory protein (StAR), which mediates the transfer of cholesterol from the cytosol to the inner mitochondrial membrane (Wang and Stocco, 1999).

\section{Body condition score and ovulation}

The change in body condition score (BCS) after calving provides a subjective estimate of the energy shortfall in an individual cow. Previous studies have demonstrated a negative relationship between the BCS loss in the early postpartum period and the interval to first ovulation (Beam and Butler, 1999; Wathes et al., 2001a). There is also a clear effect of both the BCS at calving and the BCS loss on the interval to conception (see below). Both first lactation and older cows with a high BCS loss had low IGF-I, increased $\beta$-hydroxybutyrate and NEFA concentrations in the early postpartum period (up to 5 weeks) and in the first lactation insulin concentrations were also lower (D. C. Wathes, V. J. Taylor and Z. Cheng, unpublished).

\section{NEFAs and $\beta$-hydroxybutyrate}

Dairy cows with both DOV1 and DOV2 profiles had significantly higher concentrations of NEFA and $\beta$-hydroxybutyrate at weeks $1-5$ after parturition than normal cyclic cows (Huszenicza et al., 1988). Kruip et al. (2001) developed an over-conditioned late pregnant cow model in which animals experienced severe negative energy balance after birth. There were significant relationships between blood NEFA, the liver triacyglycerol concentration and the interval to first ovulation. Primiparous cows with DOV1 also had a higher output of energy into milk (measured in MJ per week) (V. J. Taylor, unpublished). Increased milk fat has previously been noted in ketotic cows, presumably because of the increased availability of $\beta$-hydroxybutyrate and fatty acids for milk fat synthesis.

\section{Lipids}

Increasing the amount of dietary fat increases both the number of small follicles and the size of larger follicles in the bovine ovary, an effect that is independent of energy supply as it occurs with isocalorific diets (for a review, see Staples et al., 1998). Suggested mediators have included insulin, IGF-I and cholesterol, but metabolic hormone concentrations have not changed consistently in studies in which follicular parameters have altered. First lactation cows were fed diets varying in their PUFA content (Robinson et al., 2002). The high n-6 diet (LA) increased circulating cholesterol and IGF-1 concentrations, but did not influence the size or number of follicles, whereas the high n-3 diet (LNA) caused an increase in the number, size, and oestradiol production of follicles, but did not alter either cholesterol or IGF-I. Insulin was unchanged by either diet. The mechanism of action is thus far from clear, but might involve altered follicular prostaglandin production; both PGE 
and $\mathrm{PGF}_{2 \alpha}$ have been implicated in the mechanisms controlling follicular blood flow and rupture (see below). A significantly more variable interval in the time from the LH surge to ovulation was found in cows on a high n-6 diet (control, $21-24 \mathrm{~h} ; \mathrm{n}-6,18-44 \mathrm{~h}$ ), indicating a possible influence on ovulation which warrants further investigation (Robinson et al., 2002).

\section{Other factors influencing the interval to first ovulation}

Yield, age of cow and season of calving have all been shown to influence the interval to first ovulation in some, but not all, studies. This variability is not surprising as the effects are often interdependent and are influenced by management. First lactation cows produce less milk, but they also eat less and are still growing and, therefore, their energy balance is different from that of older cows (Lucy, 2001). In a sludy of 400 cows monitored with milk progesterone profiles, half of which were in their first lactation, a significant positive relationship between the interval to first ovulation and both peak and total milk yield was found when first lactation and older cows were assessed separately (D. C. Wathes, Z. Cheng and V. J. Taylor, unpublished). In a previous study in the UK, a seasonal effect and a longer interval to first ovulation was found in cows calving from March to May (Bulman and Lamming, 1978). It was not clear whether this increase was due to altered nutrition at different times of the year (for example, due to spring turn out to grass) or to a direct effect of photoperiod. In hotter climates, summer infertility due to heat stress is a well-recognized phenomenon (al-Katanani et al., 1999). It is likely that in all cases the prime factor determining when an individual cow first ovulates is related to energy balance as discussed above, and this is influenced by diet, yield, age and season in different studies.

\section{Ovulation and cyst development}

In dairy cows, follicles generally ovulate after they reach a maximum diameter of $13-20 \mathrm{~mm}$ at an interval of $24-48 \mathrm{~h}$ after an LH surge. The LH surge is responsible for differentiation of the follicular cells, which includes the switch from oestradiol to progesterone production (for a review, see Juengel and Niswender, 1999). The LH surge also activates an inflammatory reaction involving both hyperaemia and collagen degradation, which are mediated by increasing production of $\mathrm{PGE}_{2}$ and $\mathrm{PGF}_{2 \alpha}$, respectively, and which are responsible for the thinning and eventual rupture of the follicle wall (Espey, 1980).

During the period after parturition, a number of dominant follicles fail to ovulate at the appropriate time but persist for $\geqslant 10$ days. The reported incidence of dominant follicles failing to ovulate is between 6 and 19\% (Hooijer et al., 2001; Silvia et al., 2002). There is increasing evidence that the reason for the failure to ovulate is stress-induced inhibition of oestradiol positive feedback to the hypothalamus and pituitary gland, preventing the LH surge (Fig. 4). Stress induced by transportation delayed the onset of the $\mathrm{LH}$ surge and reduced its maximum concentration in ewes (Dobson and Smith, 1998). Cows treated with either ACTH or low dose progesterone, which both mimic stress-induced endocrine changes, developed persistent dominant follicles (Noble et al., 2000; Silvia et al., 2002). Ovulation can be inhibited and cyst development promoted in cows that develop mastitis or endometritis. These infections are accompanied by increased cortisol concentrations (Hockett et al, 2000) and extended follicular phases (Huszenicza et al., 1998). The relationship with yield is equivocal: some studies report a link to higher yield (for example, see Hooijer et al., 2001), whereas others do not. In contrast, Nanda et al. (1989) reported that cysts developed shortly after an unexpected fall in yield, which could 


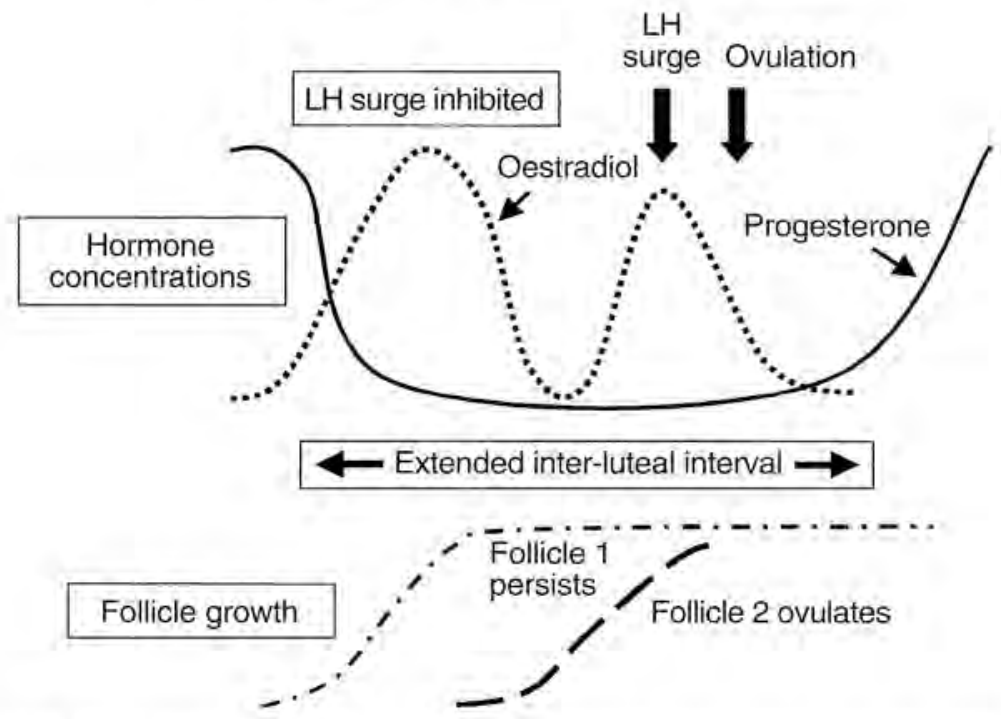

Fig. 4. Proposed events leading to extended inter-luteal intervals and persistent follicles (cysts) in postpartum cows. The L.H surge may be inhibited at the hypothalamus if the cow is subjected to stress or develops an infection during the follicular phase, despite an adequate production of oestradiol by the dominant follicle. This follicle then fails to ovulate but persists structurally. When oestradiol production by the first follicle decreases another follicle is selected and grows. After the period of stress has finished, this follicle can initiate an LH surge and ovulate.

have been indicative of some environmental factor (for example, change in diet) causing both events.

\section{Development of the corpus luteum}

\section{Links between the pre-ovulatory follicle and subsequent corpora lutea}

When judging the adequacy of the corpus luteum, the interval from ovulation to the progesterone increase, the maximum progesterone concentration reached and the duration of the luteal phase must all be considered. In a population of naturally cyclic cows selected as 'at risk' of exhibiting a delayed progesterone increase after ovulation, such delays were associated with poor oestradiol secretion during the follicular phase leading up to ovulation (Starbuck et al., 2000), but this did not occur in a population of cows exhibiting normal postovulatory progesterone increases after ovulation (G. E. Mann, E. C. L. Bleach, G. R. Starbuck and M. D. Fray, unpublished). However, in these cows, the mean plasma concentration of progesterone from day 4 to day 6 after ovulation increased significantly with increasing diameter of the ovulatory follicle and decreased with increasing time from luteolysis to ovulation. These data indicate a link between steroidogenic function in the preovulatory follicle and the post-ovulatory corpus luteum and demonstrate that increased progesterone secretion by the developing corpus luteum is related to the ovulation of a larger follicle that took less time to mature. Progesterone production during the early luteal phase is also dependent on the amount of gonadotrophin support. Inadequate gonadotrophin production after ovulation in cows is accompanied by a marked reduction in LH pulse frequency on day 5 (Starbuck et al., 2000). 


\section{Nutritional influences on luteal function}

The effects of nutrition on progesterone concentrations in cows are equivocal. In sheep, there is a strong negative correlation between dietary intake and progesterone concentrations ( $\mathrm{O}^{\prime}$ Callaghan et al., 2001). However, data from heifers are inconsistent as ad libitum feeding has been reported to increase, decrease or to have no effect on progesterone concentrations (for a review, see $\mathrm{O}^{\prime}$ Callaghan et al., 2001). In cows, a negative correlation between intake of dietary crude protein and circulating progesterone has been reported in lactating, but not in non-lactating, cows (for a review, see Butler, 1998). During lactation, luteal phase progesterone concentrations were also lower in higher yielding cows (Lucy and Crooker, 2001) and we have found a delayed increase in progesterone in the early luteal phase in cows with peak milk production of $>42 \mathrm{~kg} \mathrm{day}^{-1}$ (A. Swali, V. J. Taylor and D. C. Wathes, unpublished), although in lower yielding cows no such relationships are apparent (G. E. Mann, unpublished). Several authors have suggested that the lower progesterone is related to a greater liver mass and associated higher catabolic activity when cattle and sheep receive a greater dietary input (for example, see O'Callaghan et al., 2001).

The bovine corpus luteum can synthesize both IGF-I and -II, contains insulin and type 1 IGF receptors and responds to insulin and IGF-I in vitro by increasing progesterone output (McArdle and Holtorf, 1989; Perks et al., 1999). Growth hormone receptors are also present in large luteal cells (Lucy et al., 1993). Luteinized granulosa cells from large (> $10 \mathrm{~mm}$ ) but not smaller follicles respond to growth hormone by increasing progesterone output, an effect that was not mediated by stimulation of local IGF-I production (Gong et al., 1994; Wathes et $\left.a_{t}, 1995\right)$. Growth hormone treatment of cows (as bovine somatotrophin) can also promote luteal progesterone production in vivo (for example, see Schemm et al., 1990), although this effect is inconsistent. Therefore, all of these metabolic signals are clearly able to influence luteal function, although their precise mode of action may differ. During the early postpartum period when cows are in negative energy balance, growth hormone receptors in the liver are downregulated and the endocrine profile is of high growth hormone coupled with low insulin and IGF-I. As cows recover from negative energy balance, IGF-I increases and growth hormone decreases. Therefore, metabolic influences on the corpus luteum will vary according to the time after calving.

Robinson et al. (2002) studied the effect of dietary PUFAs on progesterone concentrations in first lactation cows. Both high $n-6$ and high $n-3$ diets delayed the timing of the progesterone increase in the luteal phase, and in cows fed the $n-3$ diet there was also a significant reduction in the peak progesterone concentration. This effect could be mediated by altered luteal prostaglandin production as both $\mathrm{PGE}_{2}$ and 6-keto-PGF $1 \alpha$ are luteotrophic in the early luteal phase (Milvae, 1986). Changes in cholesterol availability might also be mediated via regulation of StAR protein (see above).

\section{Factors influencing early embryo development}

Importance of luteal function during early pregnancy

In dairy cattle, inadequate luteal function to support normal embryo development is now established as a major reproductive problem. Repeated studies have demonstrated reduced progesterone concentrations during early pregnancy in cows in which pregnancy fails (for reviews, see Mann and Lamming, 1999; Mann et al., 1999). There is now considerable evidence that it is the time at which progesterone concentrations start to increase, rather than the final concentrations achieved, that is the critical determinant of the outcome of 


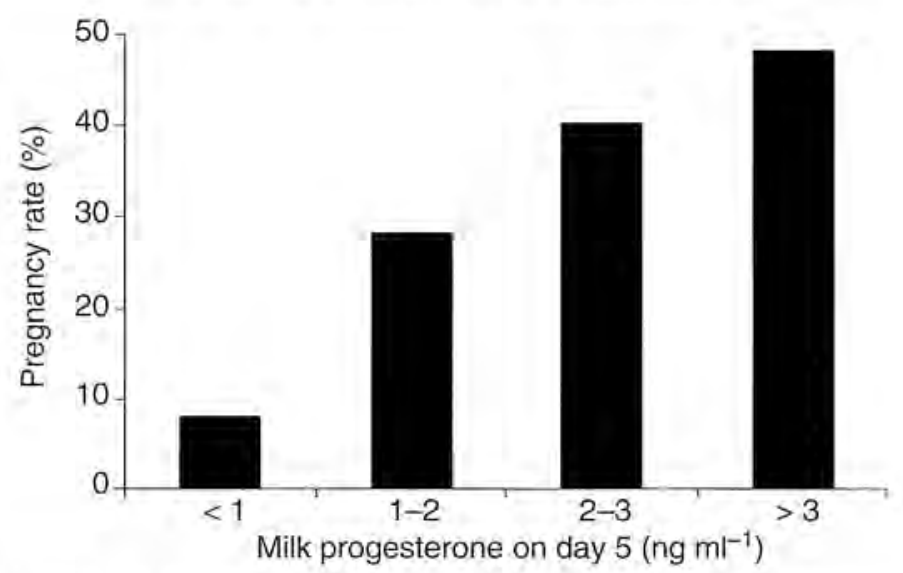

Fig. 5. Relationship between milk progesterone concentration at day 5 after mating and pregnancy rate in a survey of 1228 HolsteinFrieșian dairy cows. (Adapted from Starbuck et al., 2001).

mating. For example, by monitoring milk progesterone concentrations on day 5 after mating in over 1400 cows, Starbuck et al. (2001) showed that cows with 'adequate' milk progesterone $\left(>3 \mathrm{ng} \mathrm{ml}^{-1}\right.$ ) had pregnancy rates of approximately $50-55 \%$, whereas cows with concentrations of $<1 \mathrm{ng} \mathrm{ml}^{-1}$ had pregnancy rates $<10 \%$ (Fig. 5). Larson et al. (1997) also demonstrated a delayed onset of the progesterone increase after ovulation in cows failing to conceive.

The importance of early progesterone on the outcome of insemination is further supported by progesterone supplementation studies. In an overall analysis of 17 such studies, Mann and Lamming (1999) demonstrated a highly significant $10.3 \%$ improvement in pregnancy rate when progesterone was administered before day 6 compared with only a $1.4 \%$ increase when progesterone was administered after day 6 . Treatment of cattle with progesterone from day 2 to day 5 resulted in a tenfold increase in conceptus elongation on day 14 (Garrett et al., 1988), whereas later increases in progesterone failed to cause any marked increase in embryo development (Kerbler et al., 1997). The timing of the progesterone increase is important because it acts on progesterone receptors in the uterus to alter the pattern of uterine secretions (for a review, see Geisert et al., 1992). These secretory products in turn provide histiotrophic support for the developing embryo and thus affect its growth rate. The bovine conceptus must produce sufficient interferon tau (IFN $\tau$ ) to prevent oxytocin receptor upregulation on about day 16, which in turn initiates luteolysis (Wathes and Lamming, 1995). IFN $\tau$ is synthesized by the trophectoderm, so there is a direct relationship between the size of the embryo and IFN $\tau$ production (Mann et al., 1999; Robinson et al., 2001). We have found a strong correlation between progesterone concentrations on day 4 and day 5 after mating (but not later in the luteal phase) and the uterine concentrations of IFN- $\tau$ on day 16 , during the period of maternal recognition of pregnancy (Fig. 6). This finding again indicates that it is the timing of the progesterone increase which is critically important for embryo development.

\section{Relationship between metabolic parameters and conception rates}

Studies into the relationships between metabolic parameters and fertility have often been inconsistent (for a review, see $\mathrm{O}^{\prime}$ Callaghan et al., 2001). One reason for this 


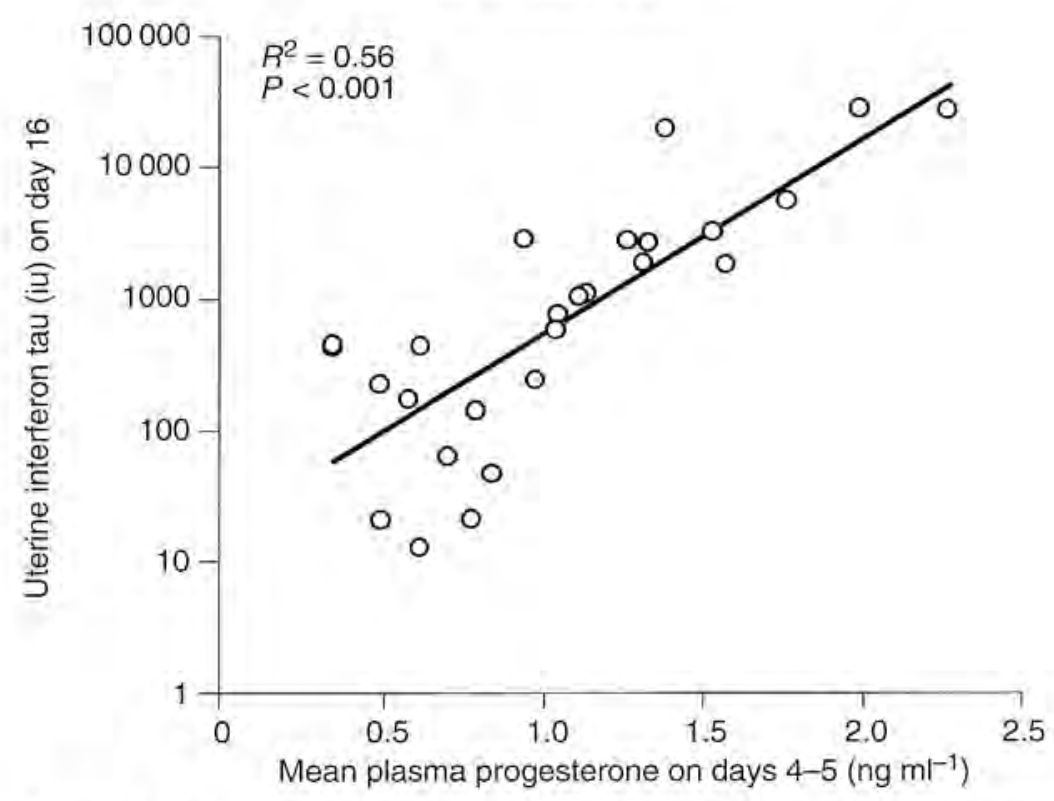

Fig. 6. Relationship between plasma progesterone concentration on days 4-5 after mating and total uterine interferon- $\tau$ on day 16 in non-lactating Holstein-Friesian cows, (Based on data from Mann et al., 2002).

is that there appears to be a carry over effect of the period of negative energy balance on to conception rates, which are not reflected by metabolic parameters measured at the time of artificial insemination (Fig. 7). Our own recent work, summarized here, has also revealed major differences between first lactation and multiparous cows, which have often not been considered in previous studies.

A variety of metabolic parameters were measured before and after calving in $>300$ multiparous cows and these were related to the interval to conception. Cows failing to conceive at all had consistently lower IGF-I concentrations both before calving and in the early postpartum period (weeks $1-7$ ) than cows that conceived, but differences were generally no longer significant during the service period (Wathes et al., 2001a), Urea concentrations increased after calving in cows with calving to conception intervals of $>150$ days, whereas urea values remained stable over this period in cows that conceived more rapidly (Wathes et al., 2001b). Therefore, the differences in urea concentrations between fertile and infertile cows were apparent later than for IGF-I. These metabolic changes in the less fertile cows were generally associated with either a large BCS loss, a low BCS at calving or a lower DMI than in more fertile cows (D. C. Wathes, Z. Cheng and V. J. Taylor, unpublished). In another study, we found that cows failing to conceive to first service had failed to regain significant amounts of condition score during the service period (G. E. Mann, unpublished).

In primiparous cows $(n=198)$, the relationships between calving to conception intervals and metabolic profiles were clearly different. Animals that failed to conceive had the highest IGF-l and urea concentrations before calving, and heifers calving with a pre-calving $\mathrm{BCS}$ of $>3$ had the longest calving to conception intervals. These cows also experienced a greater BCS loss post partum. These results indicate that fertility problems in the first lactation are triggered principally by the metabolic status at calving. There were no consistent relationships between NEFA, $\beta$-hydroxybutyrate or insulin concentrations and calving to conception intervals in either age group. 


Cow in deepest negative energy balance
- Increased lipolysis, reflected in raised NEFA and $\beta$-hydroxybutyrate concentrations
- Large BCS loss and, therefore, lower BCS at AI
- Lower IGF-I and insulin, impaired follicular development
- Inadequate follicular development resulting in poor quality corpus luteum
- High NEFAs increase triacylglycerol in oocyte and impair oocyte quality
- Low energy decreases IGF-I and increases urea production; deleterious effects on
- Immune system depressed, cow more susceptible to infection

Fig. 7. Suggested mechanisms whereby a period of severe negative energy balance in the immediate postpartum period can reduce subsequent fertility in cows. Al: artificial insemination; BCS: body condition score; IGF-I: insulin-like growth factor I; NEFA: non-esterified fatty acids.

The carry-over effects of a negative energy balance on fertility are consistent with the results of other workers who have found that oocyte quality is impaired in cows with a large BCS loss (Snijders et al, 2000) or a high liver triacylglycerol content (Kruip et al, 2001). The increasing urea concentration after birth is probably indicative of an underlying energy imbalance in individual animals, as high urea values in cows in positive energy status do not seem to have a detrimental effect on embryo survival (Laven and Drew, 1999; O'Callaghan et al., 2001).

\section{IGF system in the reproductive tract}

The association of low circulating IGF-I concentrations with poor conception rates supports proposals that the IGF system has an important role in the reproductive tract (Wathes et al., 1998). The embryo is in the oviduct for $4-5$ days before travelling to the uterus. The embryo starts to elongate from about day 13 , but does not attach to the uterine wall until day 19 , so it is entirely dependent on the secretions of the uterine tract to provide both an appropriate environment (for example, in terms of $\mathrm{pH}$ ) and nutritive support during this critical early period. The oviduct mucosa synthesizes an increasing amount of IGF-l at the time of ovulation, which presumably acts on IGF-1R which are present in both the mucosa and muscle layers (Schmidt et al., 1994; Pushpakumara et al., 2002). IGF-I may also be released into the oviductal lumen to affect embryo growth and metabolism directly (Heyner, 1997). Preliminary evidence indicates that expression of IGFBP-3 within the mucosa is higher in lactating than non-lactating cows. This difference may represent a nutritionally sensitive mechanism for reducing IGF action in the oviduct (Pushpakumara et al., 2002).

There is also an active IGF system within the bovine uterus (Geisert et al., 1991; Keller et al., 1998; Robinson et al., 2000). Local production of IGF-I by the endometrial stroma appears quite low, but there is intense expression of IGF-1R mRNA within the endometrial glands and of IGF-II mRNA in the caruncular stroma. IGFBP-1 is expressed in the luminal epithelium in the late luteal phase and is upregulated in early pregnancy. As IGFBP-1 


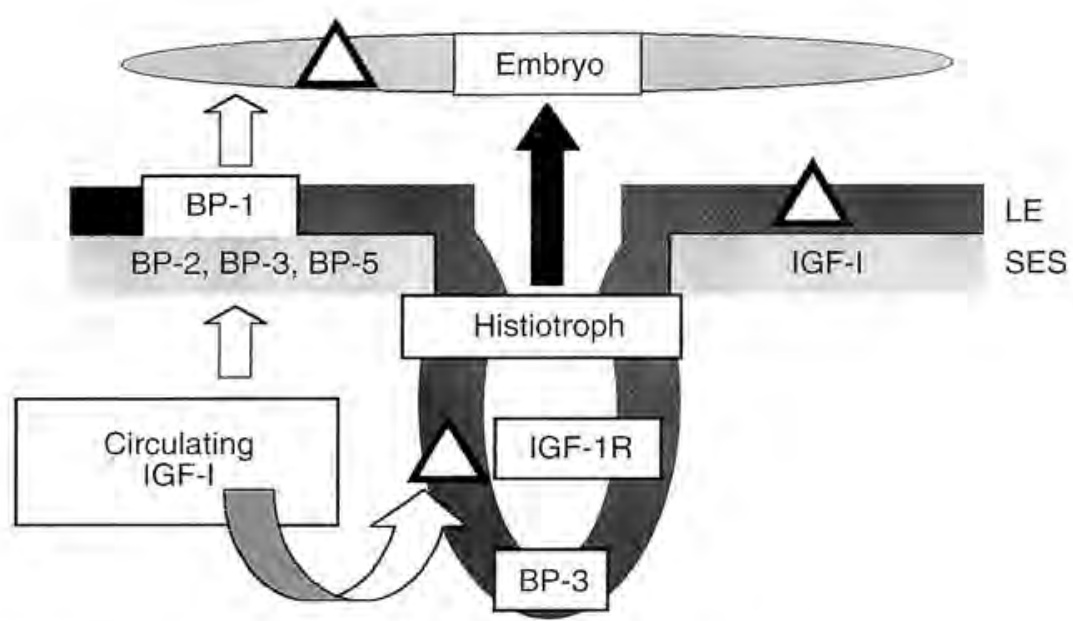

Fig. 8. The insulin-like growth factor (IGF) system in the bovine reproductive tract during conceptus elongation. Circulating IGF-I acts on type 1 IGF receptor (IGF-1R) in the glandular epithelium to promote the secretion of histiotroph. There is also low production of IGF-I in the sub-epithelial stroma (SES). Some IGF-I may transit into the uterine lumen to act directly on IGF-1R in the developing embryo. The actions of IGF-I are modulated by the production of IGF-binding proteins (BP), which are localized to the luminal epithelium (LE), SES or glandular epithelium. Pregnant cows tend to have higher circulating IGF-1 concentrations and expression of IGFBP-1 mRNA and lower expression of IGFBP-2 and -3. (Based on data from Robinson et al, 2000).

possesses an RGD domain that can recognize the $\alpha_{5} \beta_{1}$ integrin receptor on trophectoderm, its presence in the luminal epithelium at this time may be important for embryo attachment (Han and Carter, 2000). IGFBP-2 mRNA is localized to the sub-epithelial stroma with higher concentrations in cows that did not conceive to insemination. IGFBP-3 is widely expressed in the endometrium in stroma, epithelial cells and blood vessels, but the precise localization varies among cows and there are suggestions that the distribution may be nutritionally regulated and may be lower in cows that conceive. As both IGFBP-2 and IGFBP-3 can reduce IGF bioavailablity (Rechler and Clemmons, 1998), changes in binding protein expression may act in concert with alterations in circulating IGF-I to regulate IGF actions in the reproductive tract (Fig. 8).

\section{Infectious disease and fertility}

The immune system is depressed in early lactation due, in part, to increases in cortisol at parturition or in response to other stressors. Therefore, dairy cows are particularly susceptible to bacterial infection causing mastitis or endometritis, which are more likely to occur after a difficult calving (retained fetal membranes, dystocia, twins, calf mortality; Kruip et al., 2001). The endotoxins released induce the liberation of a variety of inflammatory mediators including $\mathrm{PGF}_{2 \alpha}$, lumour necrosis factor $\alpha(\mathrm{TNF} \alpha)$ and other pro-inflammatory cytokines. These factors mediate a 'reprogramming of metabolism' which preferentially targets nutrients for lymphocyte and macrophage proliferation, and production of antibodies and acute phase proteins, but away from other body functions (Spurlock, 1997). Cows with mastitis have lower circulating concentrations of IGF-I and insulin (Huszenicza et al., 1998), whereas cows with 
higher circulating concentrations of IGF-I can mount a better immune response (Mallard etal., 1997). Cows with metabolic disorders, such as hepatic lipidosis, also have reduced immune competence.

Thus, it is not surprising that common infections can impact on fertility. Huszenicza et al. (1998) found that the development of mastitis in the follicular phase of the cycle was associated with an extended inter-luteal interval from $8 \pm 2$ to $14 \pm 8$ days. A longer anovulatory period after birth and follicular cysts are more common in cows with endometritis (Hussain and Daniel, 1991) indicating that ovarian and uterine function is impaired. This finding is supported by Spicer (2001b) who demonstrated that TNF $\alpha$ can decrease IGF-I stimulated follicular steroid production. Inflammatory cytokines may also act at the hypothalamus to inhibit LHRH.

The incidence of persistent luteal phases (increased progesterone for $>19$ days) has increased over the past 30 years (Royal et al., 2000). Risk factors for persistent luteal phases are an abnormal calving, retained placenta and metritis, although many cows with persistent luteal phase show no obvious signs of uterine infection. The incidence of persistent luteal phases also increases with age and in cows that have their first ovulation < 19 days post partum, before uterine involution has occurred (Opsomer et al., 1998) and is higher in US Holstein than in New Zealand Friesian cows (Lucy, 2001). Cows with uterine infection have prolonged secretion of $\mathrm{PGF}_{2 \alpha}$ post partum (Bekana et al., 1996), which may be in response to lipopolysaccharide stimulation (Leung et al., 2001). Despite this, the duration of the luteal phase is more often lengthened than shortened, possibly because the pattern of $\mathrm{PGF}_{2 \alpha}$ release is inappropriate to trigger luteolysis. Leung et al. (2001) have shown that the pro-inflammatory interleukins $-1,-2$ and -6 can inhibit development of oxytocin receptors in the bovine endometrium.

The incidence of persistent luteal phases also increases during heat stress, possibly in association with reduced follicular oestradiol production (Lucy, 2001). However, we and others were unable to demonstrate any major changes in metabolic hormone profiles indicative of a prolonged negative energy balance post partum in cows that developed persistent luteal phase profiles (Huszenicza et al., 1988; V. J. Taylor and D. C. Wathes, unpublished). There is a well-established relationship between endometritis and fertility: infected cows have a prolonged interval to first service, more services per conception and an increased calving to conception interval (Dobson and Smith, 1998).

A number of other infectious diseases have been associated with reduced fertility in dairy cattle. For example, bovine viral diarrhoea virus (BVDV) can reduce conception rates by up to $50 \%$. The causal mechanisms have again not been fully elucidated, but experimental infection with BVDV, such that peak viraemia occurred during pre-ovulatory follicle development, caused significantly lower progesterone concentrations during the ensuing luteal phase (Fray et al., 2002).

\section{Conclusions}

Many studies have now shown that ovarian cyclicity in postpartum dairy cows is often extremely irregular. Ovarian cycles may not resume until some considerable time after calving. When they do, long inter-luteal intervals and both short and long luteal phases are all commonly observed. The steady increase in yield over the past 30 years has placed cows under increasing metabolic demands which challenge their ability to supply adequate nutrients to body systems other than the mammary gland. All mammals have evolved strategies to prevent reproduction at times of nutrient shortage or stress. In dairy cows this manifests itself as inhibition of pulsatile LH secretion, reduced follicular and luteal growth, impaired 
oocyte quality and a poor environment in the reproductive tract related to the time of the progesterone increase. It is hardly surprising that fertility rates are often so poor. Under these conditions, many aspects of dairy cow management become crucial in determining whether an individual cow will conceive at the desired time after calving. The diet needs to contain the correct protein:energy ratio and sufficient dry matter intake must be achieved to counteract the drain of lactation. Many individual dietary constituents also seem to influence reproductive performance, although the mechanisms of action in many cases remain elusive. It is also increasingly apparent that nutritional management before calving plays a critical role in determining subsequent fertility, via alterations in milk yield, BCS loss and calving difficulty. The process of calving followed by the metabolic drain of lactation also impact on the immune system, making cows susceptible to diseases such as mastitis and metritis. These diseases also reduce fertility through inhibition of hypothalamic and pituitary function as well as having direct effects on the ovary and uterus.

The authors thank DEFRA, the Milk Development Council and the BBSRC for funding studies in the authors' laboratories. The authors are also grateful to the many colleagues who contributed to the work described and to the animal technicians for their care of the animals.

\section{References}

Abayasekara DRE and Wathes DC (1999) Effects of altering dietary fatty acid composition on prostaglandin metabolism and fertility Prostaglandins, Leukotrienes and Essential Fatty Acids $61275-287$

Adam CL, Gadd TS, Findlay PA and Wathes DC (2000) Insulin-like growth factor (IGF)-I stimulation of luteinizing hormone secretion, and expression of $m$ RNAs for IGFs, their receptors and binding proteins in the ovine pituitary gland Journal of Endocrinology $166247-254$

al-Katanani YM, Webb DW and Hansen PJ (1999) Factors affecting seasonal variation in 90-day nonreturn rate to first service in lactating Holstein cows in a hot climate Journal of Dairy Science 822611 2616

Armstrong DG, Hogg CO, Campbell BK and Webb R (1996) Insulin-like growth factor (IGF)-binding protein production by primary cultures of ovine granulosa and theca cells. The effects of IGF-1, gonadotrophin and follicle size Biology of Reproduction $\mathbf{5 5}$ 1163-1171

Austin EJ, Mihm M, Evans AC, Knight PG, Ireland JL, Ireland JJ and Roche JF (2001) Alterations in intrafollicular regulatory factors and apoptosis during selection of follicles in the first follicular wave of the bovine estrous cycle Biology of Reproduction 64 $839-848$

Bao B and Garverick HA (1998) Expression of steroidogenic enzyme and gonadotropin receptor genes in bovine follicles during ovarian follicular waves: a review Journal of Animal Science 76 1903-1921

Beam SW and Butler WR (1999) Effects of energy balance on follicular development and first ovulation in postpartum dairy cows Journal of Reproduction and Fertility Supplement 54 411-424

Bekana M, Odensvik K and Kindahl W (1996) Prostaglandin $F_{2}$ alpha metabolite and progesterone profiles in post-partum cows with retained fetal membranes Acta Veterinaria Scandinavica 37 171-185

Block SS, Butler WR, Ehrhardt RA, Bell AW, Van Amburgh ME and Boisclair YR (2001) Decreased concentration of plasma leptin in periparturient dairy cows is caused by negative energy balance lournal of Endocrinology $171339-348$

Bulman DC and Lamming GE (1978) Milk progesterone levels in relation to conception, repeat breeding and factors influencing acyclicity in dairy cows Journal of Reproduction and Fertility 54 447-458

Bulman DC and Wood PDP (1980) Abnormal patterns of ovarian activity in dairy cows and their relationships with reproductive performance Animal Production $30177-188$

Butler WR (1998) Review: effect of protein nutrition on ovarian and uterine physiology in dairy cattle Journal of Dairy Science 81 2533-2539

Butler WR (2001) Nutritional effects on resumption of ovarian cyclicity and conception rate in postpartum dairy cows British Society of Animal Science Occasional Publication 26 133-146

Dobson H and Smith RF (1998) Stress and subfertility Reproduction in Domestic Animals 33 107-112

Espey LL. (1980) Ovulation as an inflammation reaction - a hypothesis Biology of Reproduction 22 73-106

Fray MD, Mann GE, Bleach, Knight PG, Clark MC and Charleston B (2002) Modulation of sex steroid hormone secretion in the cow by acute infection with 
bovine viral diarrhoea virus Reproduction 123281 289

Funston RN, Seidel GE, Klindt J and Roberts AJ (1996) Insulin-like growth factor I and insulin-like growth factor-binding proteins in bovine serum and follicular fluid before and after the preovulatory surge of luteinizing hormone Biology of Reproduction $\mathbf{5 5}$ 1390-1396

Garrett JE, Geisert RD, Zavy MT and Morgan GL (1988) Evidence for maternal regulation of early conceptus growth and development in beef cattle Journal of Reproduction and Fertility 84 437-446

Geisert RD, Lee CY, Simmen FA, Zavy MT, Fliss AE, Bazer FW and Simmen RCM (1991) Expression of mRNAs encoding insulin-like growth factor-1, -11 and insulin-like growth factor binding protein- 2 in bovine endometrium during the estrous cycle and early pregnancy Biology of Reproduction 45 975-983

Geisert RD, Morgan GL, Short EC, Jr and Zavy MT (1992) Endocrine events associated with endometrial function and conceptus development in cattle Reproduction, Fertility and Development 4 301-305

Gong JG, McBride D, Bramley TA and Webb R (1993) Effects of recombinant bovine somatotrophir, insulin-like growth factor I and insulin on the proliferation of bovine granulosa cells in vitro Journal of Endocrinology $13967-75$

Gong JG, McBride D, Bramley TA and Webb R (1994) Effects of recombinant bovine somatotrophin, insulin-like growth factor I and insulin on bovine granulosa cell steroidogenesis in vitro. Journal of Endocrinology 143 157-164

Han VKM and Carter AM (2000) Spatial and temporal patterns of expression of mRNA for insulin-like growth factors and their binding proteins in the placenta of man and laboratory animals Placenta 21 289-305

Heyner S (1997) Growth factors in preimplantation development: role of insulin and insulin-like growth factors Early Pregnancy 3 153-163

Hockett ME, Hopkins FM, Lewis MJ, Saxton AM, Dowlen $\mathrm{HH}$ and Olive Schrick FN (2000) Endocrine profiles of dairy cows following experimentally induced clinical mastitis during early lactation Animal Reproduction Science 58 241-251

Hooijer GA, Lubbers RB, Ducro BJ, van Arendonk IA, Kaal-Lansbergen LM and van der Lende $T$ (2001) Genetic parameters for cystic ovarian disease in dutch black and white dairy cattle Journal of Dairy Science 84 286-291

Hussain AM and Daniel RC (1991) Bovine endometritis: current and future alternative therapy Zentralblatt fur Veterinarmedizin A 38 641-651

Huszenicza G, Haraszti J, Molnar L, Solti L, Fekete S, Ekes K and Yaro AC (1988) Some metabolic characteristics of dairy cows with different post partum ovarian function Journal of Veterinary Medicine $\mathbf{3 5}$ 506-515
Huszenicza G, Janosi S, Kulcsar M, Korodi P, Dieleman SI, Bartyik J, Rudas P and Ribiczei-Szabo P (1998) Gram-negative mastitis in early lactation may interfere with ovarian and certain endocrine functions and metabolism in dairy cows Reproduction in Domestic Animals 33 147-154

Inskeep EK, Braden TD, Lewis PE and Niswender GD (1988) Receptors for luteinizing hormone and follicle stimulating hormone in largest follicles of post partum beef cows Biology of Reproduction $\mathbf{3 8}$ 587-591

Juengel JL and Niswender GD (1999) Molecular regulation of luteal progesterone synthesis in domestic ruminants Journal of Reproduction and Fertility Supplement 54 193-205

Kadokawa $H$, Blache D, Yamada $Y$ and Martin GB (2000) Relationships between changes in plasma concentrations of leptin before and after parturition and the timing of first post partum ovulation in high producing Holstein dairy cows Reproduction, Fertility and Development 12 405-411

Keisler DH, Daniel JA and Morrison CD (1999) The role of leptin in nutritional status and reproductive function Journal of Reproduction and Fertility Supplement 54 425-435

Keller ML, Roberts AJ and Seidel GE (1998) Insulinlike growth factor binding proteins in the uterus and embryos during early embryonic elongation in cattle Biology of Reproduction 59 632-642

Kerbler TL, Buhr MM, Jordan LT, Leslie KE and Walton IS (1997) Relationship between maternal plasma progesterone concentration and interferon- $\tau$ synthesis by the conceptus in cattle Theriogenology $47703-$ 714

Kruip TAM, Wensing T and Vos PLAM (2001) Characteristics of abnormal puerperium in dairy cattle and the rationale for common treatments British Society of Animal Science Occasional Publication 26 63-80

Larson SF, Butler WR and Currie WB (1997) Reduced fertility associated with low progesterone postbreeding and increased milk urea nitrogen in lactating cows Journal of Dairy Science 80 1288-1295

Laven RA and Drew SB (1999) Dietary protein and the reproductive performance of cows Veterinary Record $145687-695$

Leung ST, Cheng Z, Sheldrick EL, Derecka K, Flint APF and Wathes DC (2001) The effects of lipopolysaccharide and interlukins- $1 \alpha,-2$ and -6 on oxytocin receptor expression and prostaglandin production in bovine endometrium Journal of Endocrinology 168 497-508

Lucy MC (2001) Reproductive loss in high-producing dairy cattle: where will it end? Journal of Dairy Science 84 1277-1293

Lucy MC and Crooker BA (2001) Physiological and genetic differences between low and high index dairy cows British Society of Animal Science Occasional Publication 26 223-234 
Lucy MC, Collier RJ, Kitchell ML, Dibner JJ, Hauser SD and Krivi GG (1993) Immunohistochemical and nucleic acid analysis of somatotropin receptor pópulations in the bovine ovary Biology of Reproduction 48 1219-1227

McArdle CA and Holtorf AP (1989) Oxytocin and progesterone release from bovine corpus luteal cells in culture: effects of insulin-like growth factor I, insulin and prostaglandins Endocrinology 124 1278-1286

Mallard BA, Wagter LC, Ireland MJ and Dekkers IC (1997) Effects of growth hormone, insulin-like growth factor-1 and cortisol on periparturient antibody response profiles of dairy cattle Veterinary Immunology and Immunopathology $6061-76$

Mann GE and Lamming GE (1999) The influence of progesterone during early pregnancy in cattle Reproduction in Domestic Animals 34 269-274

Mann GE, Lamming GE, Robinson RS and Wathes DC (1999) The regulation of interferon-tau production and uterine hormone receptors during early pregnancy Journal of Reproduction and Fertility Supplement $54317-328$

Mann GE, Fray MD, Robinson RS, Wathes DC and Lamming GE (2002) Interferon tau production during early pregnancy in the cow Biology of Reproduction 66 Supplement 1 (Abstract 120)

Mattos R, Staples CR and Thatcher WW (2000) Effects of dietary fatty acids on reproduction in ruminants Reviews of Reproduction 5 38-45

Milvae RA (1986) Role of luteal prostaglandins in the control of bovine corpus luteum functions Journal of Animal Science 62 Supplement 2 72-78

Nanda AS, Ward WR and Dobson H (1989) The relationship between milk yield and cystic ovarian disease in cattle British Veterinary Journal 145 39-45

National Research Council (1989) Nutrient Requirements for Dairy Cattle 6th Edn National Academy Press, Washington DC

Noble KM, Tebble JE, Harvey D and Dobson H (2000) Ultrasonography and hormone profiles of persistent ovarian follicles (cysts) induced with low doses of progesterone in cattle Journal of Reproduction and Fertility $120361-366$

O'Callaghan D, Lozano JM, Fahey J, Gath V, Snijders $S$ and Boland MP (2001) Relationships between nutrition and fertility in dairy cattle British Society of Animal Science Occasional Publication 26 147-160

Opsomer G, Coryn M, Deluyker $\mathrm{H}$ and de Kruif A (1998) An analaysis of ovarian dysfunction in high yielding dairy cows after calving based on progesterone profiles Reproduction in Domestic Animals 33 193-204

Perks CM, Peters AR and Wathes DC (1999) Follicular and luteal expression of insulin-like growth factors I and $I$ and the type 1 IGF receptor in the bovine ovary Journal of Reproduction and Fertility $116157-165$

Pushpakumara PGA, Robinson RS, Demmers KJ, Mann GE, Sinclair KD, Webb $R$ and Wathes DC
(2002) Expression of the insulin-like growth factor (IGF) system in the bovine oviduct at oestrus and during early pregnancy Reproduction 123 859-868

Rajaram S, Baylink DJ and Mohan S (1997) Insulin-like growth factor-binding proteins in serum and other biological fluids: regulation and functions Endocrine Reviews 18 801-831

Rechler MM and Clemmons DR (1998) Regulatory actions of insulin-like growth factor binding proteins Trends in Endocrinology and Metabolism 9 176-183

Roberts AJ, Nugent RA, Klindt J and Jenkins TG (1997) Circulating insulin-like growth factor I, insulin-like growth factor binding proteins, growth hormone and resumption of estrus in postpartum cows subjected to dietary energy restriction Journal of Animal Science 75 1909-1917

Robinson RS, Mann GE, Gadd TS, Lamming GE and Wathes DC (2000) The expression of the IGF system in the bovine uterus throughout the oestrous cycle and early pregnancy Journal of Endocrinology 165 231-243

Robinson RS, Mann GE, Lamming GE and Wathes DC (2001) Embryonic-endometrial interactions during early pregnancy in cows British Society of Animal Science Occasional Publication $26289-295$

Robinson RS, Pushpakumara PGA, Cheng Z, Peters AR, Abayasekara DRE and Wathes DC (2002) Effects of dietary polyunsaturated fatty acids on ovarian function in lactating dairy cows Reproduction 124119 131

Roche F and Diskin MG (2001) Resumption of reproductive activity in the early postpartum period of cows British Society of Animal Science Occasional Publication $2631-42$

Royal M, Mann GE and Flint APF (2000) Strategies for reversing the trend towards subfertility in dairy cattle The Veterinary Journal $16053-60$

Schemm SR, Deaver DR, Griel LC and Muller LD (1990) Effects of recombinant bovine somatotropin on luteinizing hormone and ovarian function in lactating dairy cows Biology of Reproduction 42 815-821

Schmidt A, Einspanier R, Amselgruber W, Sinowatz F and Scams D (1994) Expression of insulin-like growth factor 1 (IGF-I) in the bovine oviduct during the oestrous cycle Experimental Clinical Endocrinology 102 364369

Silvia WJ, Hatler TB, Nugent AM and Laranja da Fonseca LF (2002) Ovarian follicular cysts in dairy cows: an abnormality in folliculogenesis Domestic Animal Endocrinology 23 167-177

Snijders SEM, Dillon $\mathrm{P}, \mathrm{O}^{\prime}$ Callaghan $\mathrm{D}$ and Boland MP (2000) Effect of genetic merit, milk yield, body condition and lactation number on in vitro oocyte development in dairy cows Theriogenology 53 981-989

Snyder JL, Clapper IA, Roberts AJ, Sanson DW, Hamernik DL and Moss GE (1999) Insulin-like growth factor- - , insulin-like growth factor binding 
proteins, and gonadotrophins in the hypothalamicpituitary axis and serum of nutrient restricted ewes Biology of Reproduction $61219-224$

Spicer LJ (200ta) Leptin: a possible metabolic signal affecting reproduction Domestic Animal Endocrinology $21251-270$

Spicer L) (2001b) Receptors for insulin-like growth factor $I$ and tumor necrosis factor- $\alpha$ are hormonally regulated in bovine granulosa and thecal cells $A_{n-}$ imal Reproduction Science 67 45-58

Spicer LJ and Echternkamp SE (1995) The ovarian insulin and insulin-like growth factor system with an emphasis on domestic animals Domestic Animal Endocrinology 12 223-245

Spurlock ME (1997) Regulation of metabolism and growth during immune challenge: an overview of cytokine function Journal of Animal Science $751773-$ 1783

Staples CR, Burke JM and Thatcher WW (1998) Influence of supplemental fats on reproductive tissues and performance of lactating cows Journal of Dairy Science 81 856-871

Starbuck GR, Gutierrez CG and Mann GE (2000) Relationships between pre- and post-ovulatory steroidogenic function in vivo in cattle Journal of Reproduction and Fertility Abstract Series 25 (Abstract 55)

Starbuck GR, Darwash AO, Mann GE and Lamming GE (2001) The detection and treatment of post insemination progesterone insufficiency in dairy cows British Society of Animal Science Occasional Publication $26-447-450$
Tsuchiya T, Nagao Y, Ozawa A, Matsumoto M, Sugahara K, Kubo T and Kato H (1998) Decrease of the obese gene expression in bovine subcutaneous adipose tissue by fasting Bioscience, Biotechnology and Biochemistry 62 2068-2069

Wang $X$ and Stocco DM (1999) Cyclic AMP and arachidonic acid: a tale of two pathways Molecular and Cellular Endocrinalogy 158 7-12

Wathes DC (1992) Embryonic mortality and the uterine environment (Commentary) Journal of Endocinology $134321-325$

Wathes DC and Lamming GE (1995) The oxytocin receptor, luteolysis and the maintenance of pregnancy Journal of Reproduction and Fertility Supplement 49 53-67

Wathes DC, Perks CM, Davis AJ and Denning-Kendall PA (1995) Regulation of insulin-like growth factor $I$ and progesterone synthesis by fosulin and growth hormone in the ovine ovary Biology of Reproduction $53882-889$

Wathes DC, Reynolds TS, Robinson RS and Stevenson KR (1998) Role of the insulin-like growth factor system in uterine function and placental development in ruminants fournal of Dairy Science 81 1778-1789

Wathes DC, Taylor VI and Cheng Z (2001a) Metabolic interactions with fertility Cattle Practice 9 291-296

Wathes DC, Beever DE, Cheng Z, Pushpakumara PGA and Taylor VJ (2001b) Lifetime organization and management of reproduction in the dairy cow British Society of Animal Science Occasional Publication 28 59-69 